\title{
Improving Assertive Attitude Through Assertive Trainning Techniques for Deaf Student
}

\author{
Faiz Noormiyanto \\ Special Education Department \\ Universitas PGRI Yogyakarta \\ Yogyakarta, Indonesia \\ faiz@upy.ac.id
}

\begin{abstract}
The phenomenon of hearing impaired students who have a low assertive attitude which has an impact on the ability of the social interaction of hearing impairments in daily life. Assertiveness is very important to be applied in everyday life, especially in expressing feelings and opinions that are in accordance with the wishes and feelings of individuals. Lack of assertiveness will have an impact on lack of self-actualization, lack of stance, difficulty in making their own decisions and tend to be obedient to what others command without heeding their own feelings. The purpose of this study is to increase assertiveness with assertive training techniques to improve assertiveness in students with hearing impairment. the development of assertiveness can be seen from how far individuals are able to actualize what they want, express their personal opinions, have a position and get prosperity for what is their decision. The type of research used is descriptive qualitative research. The research subjects were deaf disabled students at SMALB B SLB Negeri 1 Bantul Data collection used questionnaires, documentation and interviews. Data collection techniques used were interactive miles and hubberman analysis. The results of this study indicate that the factual conditions of deaf disability assertiveness after following the Assertive Training process experienced an increase marked by deaf disabled students able to respect the rights of themselves and others, dare to express opinions in public, during learning and in association, honest with oneself and others, able to determine attitudes by paying attention to the situation and conditions around, able to use body language in accordance with the feelings that are owned. Higher education is expected to help students to master social skills and to adapt to the surrounding environment. Students with special needs have the same rights to get treatment and interact with others. This study aims to determine whether cooperative learning method could improve social skills for students with special needs. This study used Quasi Experiment approach with One Group Pre and Posttest Design. This study use purposive sampling technique to choose relevant subject for the research. The subjects of this study were 8 students with special needs. The results of statistical calculation between the results of pretest and posttest obtained the value of $F=\mathbf{1 . 2 7 5}$ shows significant influence on social skills between before and after treatment in the form of cooperative learning were given. Cooperative learning method can improve social skills of students with special needs at Special Needs Education Program of Lambung Mangkurat University, Banjarmasin.
\end{abstract}

Keywords- hearing impairment, assertiveness, assertive training.

\section{INTRODUCTION}

Deaf disability is one of the disabilities who have rights as citizens to have education, organization, health services and access to information. In essence deafness is a genetic term indicating a hearing intake problem ranges from the subsets deaf and hard of hearing. The person with hearing disability will be successful in processing linguistic information through audio, with or without a hauling aid. He/she has a residual hearing sufficient to enable the success of processing linguistic information through audition. According to [1].

Looking at the results of the National Socio-Economic Survey (Susenas) carried out by the Central Bureau of Statistics (BPS) in 2012, the number of people with disabilities in Indonesia was 6,008,661 people. Of these, around 1,780,200 people were those with visual disabilities; 472,855 were people with disabilities of hearing; 402,817 were people with intellectual disabilities; 616,387 were people with disabilities, 170,120 were people with disabilities who were difficult to take care of themselves, and around 2,401,592 were people experiencing multiple disabilities.

The data above show that there are 472,855 people with disabilities who are deaf and speechless in Indonesia. The main problem with hearing impairment is to communicate with other people who are identical with the social environment in which they interact both in the school environment and in the environment in which they live. In addition, when a person interacts, what is expected is a psychologically supportive atmosphere, so that prosperity and happiness can be achieved. However, the reality is not as imagined because there are several factors that influence the process of language adjustment in communication.

Lack of understanding of spoken or written language often causes deaf disability to interpret something as limited as its understanding and this often becomes a problem for him. The pressure on his emotions can hamper his personal development by displaying an attitude of rejection, acting aggressively, or vice versa revealing indecision and doubt. Emotions of children with hearing impairment are always turbulent. This is caused by the poverty of the language and the influence it receives from outside. Children with hearing impairment when reminded by a hearing person who is not familiar with spoken language will seem difficult to catch the 
words of the person and they cannot understand what is being said due to the use of different languages.

The development of understanding oral language further requires special and intensive coaching in accordance with the level of hearing impairment and other abilities. Assertive behavior is a translation of assertiveness or assertion, which means the midpoint between non assertive behavior and aggressive behavior. [2] suggests assertiveness as a behavior that shows the ability to communicate what is desired, felt and thought to others but while maintaining and respecting the rights and feelings of others. Someone is said to be assertive if he/she is able to be sincere and honest in expressing feelings, thoughts and views on other parties so as not to harm or threaten the integrity of others.

Individuals who behave assertively means being able to express their thoughts and feelings honestly and relatively easily. Assertive people aim at goals, honest, open, and confident. Assertive behavior contains the behavior of community ability, empathy and communicates both verbally and non-verbally. Individuals with high assertiveness are aware of the strengths owned and view these advantages as more important than their weaknesses, and vice versa. A person's assertiveness can be demonstrated by communicating needs, desires, feelings or opinions to others in a direct and honest way without intending to hurt anyone's feelings. In general, an assertive person in his daily life is able to know himself well, so as to be able to determine the choice of desires and goals of his life without having to influence others. Based on the description above, it is important to improve assertiveness with assertive training techniques for deaf students. The purpose of this study is to increase assertiveness with assertive training techniques to improve assertiveness in students with hearing impairment. the development of assertiveness can be seen from how far individuals are able to actualize what they want, express their personal opinions, have a position and get prosperity for what is their decision.

\section{LITERATURE REVIEW}

\section{A. Deaf}

Many terms are known to mention a condition of hearing abnormalities, one of which is hearing impairment. According to Law No. 8 of 2016 the use of tuna in all disabled people is changed to disability, but in books and journals they still use deaf terminology derived from two words, namely tuna and deaf. Tuna means less while hearing means hearing. A person or child is said to be deaf if he is lacking or unable to hear.

Many definitions are used to describe a state of hearing loss or hearing impairment. Basically all definitions used have almost the same meaning. One definition of deafness is expressed by Boothroyd. According to Boothroyd "Deafness (hearing impairment) is a term used to refer to all disturbances in hearing power, regardless of the nature, causal factors and level or degree of hearing loss [3]. Deaf people are people who experience a lack or loss of hearing ability caused by damage or malfunction of some or all of the hearing devices so that they experience obstacles in the development of their language. They need special guidance and education to achieve a decent inner life.

From some definitions of hearing impairment above, it can be concluded that hearing impairment is a person who experiences a lack or loss of hearing ability caused by damage or non-functioning of some or all of the hearing devices, resulting in a person unable to capture various stimuli, especially through his sense of hearing. The inability of the hearing senses to capture sound stimuli causes speech disturbances and difficulties in understanding oral language for people with hearing impairment. Deaf children are in need of special services, both education and health, to overcome communication barriers and other problems they experience as a result of their lack of hearing.

Assertive behavior contains the behavior of community ability, empathy and communicates both verbally and nonverbally. Individuals with high assertiveness are aware of the strengths that are owned and view these advantages as more important than their weaknesses, and vice versa. A person's assertiveness can be demonstrated by communicating needs, desires, feelings or opinions to others in a direct and honest way without intending to hurt anyone's feelings. In general, an assertive person in his daily life is able to know himself well, so as to determine the choice of desires and goals of his life without having to influence others. Based on the above description it is important to improve assertiveness with assertive training techniques for deaf disabled students .

\section{B. Assertive Training For Decision Making}

Assertive raining according to [4] is a therapeutic strategy in the behavioral approach used to develop assertiveness in the client. Assertive practice sthat can be applied primarily to interpersonal situations where individuals have difficulty in accepting the fact that expressing and asserting them is an appropriate and righteous action. While the assertive sense itself in accordance with Alberti and Emmons [4] presents the working definition of assertive behavior by stating that assertive behavior develops equal rights in human relations, allows us to act freely without feeling anxious, to express feelings happily and honest, use personal rights without ignoring the rights or interests of others.

\section{METHOD}

This type of research is descriptive qualitative research where the main data source is in the form of words and actions of the research subjects observed or interviewed. It is descriptive because this research is intended to describe the situation. This study took place at SMALB B SLB Negeri 1 Bantul, therefore this study was classified in field research. Field research is research using information obtained from research objectives, hereinafter referred to as informants or respondents through data collection instruments such as observation, interviews, and questionnaires and so on. According to [5] field research is research that data collection is carried out in the field using qualitative research that produces data in the form of written or oral words from the person being studied and all kinds of behavior can also be observed 
This research was carried out at SMALB B SLB Negeri 1 Bantul, one of the most comprehensive schools in all levels in Yogyakarta. Subjects were students of SMB B SLB Negeri 1 Bantul, with samples taken purposively. Data processing and analysis techniques used data collection, data presentation, data reduction, and conclusion drawing.

\section{RESULT AND DISCUSSION}

The deaf are students and also part of the community who are required to be able to communicate with other people in the environment. The intended environment includes schools. Almost all of the student's time is widely used to interact in school. The task of students in school is learning. By learning students will get positive changes and can develop optimally, cognitive, affective, and psychomotor so that they are ready to carry out their role in the future. Of course in social interaction students are expected to be assertive, good in expressing opinions and in communicating with the environment in accordance with the developmental tasks that exist. Zastrow [4] also presents the characteristics of assertive individual interactions, namely: respond spontaneously, speak with a decent tone and volume, look at the other person, talk on issues, express feelings and opinions openly, see he is the same as others, does not hurt himself or others.

Assertive behavior needs to be known early by individuals, especially SMALB B students who have hearing impairments and who are in their early teens. Disability adolescents need to be told why assertive behavior is important in communicating even though they have communication implications. [6] suggested that students, especially those aged 13-15 years need to learn assertive behavior, because of the following benefits: 1) assertive attitudes and behaviors will make it easier for teenagers to socialize and establish relationships with the environment, especially fellow age outside the environment effectively. 2), the ability to express what they feel and want directly, frankly, then students can avoid the appearance of tensions and feelings of discomfort due to holding and storing something they want to express. 3) students can easily find solutions and solutions to various difficulties or problems they face effectively, so that the problem will not be a burden of a protracted mind. 4), assertiveness will help students to improve their cognitive abilities, broaden their horizons about the environment and not easily stop at something they don't know. 5) assertiveness towards other people who behave or behave inappropriately can help the teenagers concerned to better understand their own weaknesses and are willing to correct these weaknesses or shortcomings. Some of the benefits of assertive behavior above indicate the need for early learning of this behavior for students.

Assertiveness is not something outward. The assertiveness is a learned behavior, as a reaction to various social situations that occur in the environment. Assertive behavior is in line with a person's age so that mastery of assertive behavior in the early periods of development will have a positive impact on the development of the next period [7]. If this assertive behavior is not learned early, students will have difficulty in communicating with others assertively.
The behavior of students who are less assertive is seen as less than ideal behavior because it can have a negative impact on students themselves and their social environment because of the obstacles they have. Therefore, assertive training is needed to develop students' assertive behavior. Forms of assertive behavior can reject something that is contrary to him (able to express feelings both positive and negative), respect the rights of others, can express the right ideas or opinions without being ashamed, direct and firm, and dare to determine the attitude to be responsible. [2]. The findings of the above researchers can show that the role of assertive training has several benefits for the disability, one of which is the teacher can guide and control the assertive attitudes of students in their social life and in the family. Deficiency in hearing does have a significant impact on hearing impairment assertiveness.

Looking at the various phenomena and findings during assertive role training research, the researchers concluded that assertive training can control and improve the assertive attitude of deaf disabled students. The improvement of deaf disability assertiveness can be characterized by the factual condition of assertiveness now. After assertive training in hearing impaired students can express feelings to his friends the students dared to express anger to his friends who made mistakes on him, dared to believe in his own abilities when working on assignments, believed in his own work, dared to say no if they were asked to do something if they were asked to do something violating, dared to tell a friend to explain slowly, used oral language slowly of a new understanding, and dared to express his opinion. The intended behaviors include: fighting for rights (standing up for you rights), helping others (helping others), giving direction (giving instructions), submitting complaints (making a complaint), responding to complaints (answering a complaint), negotiations (negotiations ), self-control, influence / persuasion, responding to persuasion or responding, and managing group pressure (dealing with pressure).

\section{CONCLUSION}

Based on the results of the research conducted, there are several conclusions, including the factual condition of assertiveness now after undergoing assertive training in deaf disabled students can already express their feelings to their friends as students have dared to express anger to their friends who make mistakes in themselves, have dared to believe in their own abilities, while working on assignments in teaching and learning already believe in the job itself, students have dared to say no if asked by his friend to do something that is violating, to ask the purpose and reason, say no if asked by his friend to do something that is violating, now if asked to ask the purpose and reason, dare to tell friend to explain slowly by using oral language slowly after the new understanding the student dares to express his opinion. Students with disabilities experience an increase in assertiveness, which is marked by students with hearing impairment able to respect the rights of themselves and others, dare to express opinions in public, at the time of learning or in association, honest with themselves and others, able to determine attitudes by paying attention to the situation and surrounding conditions, able to use body language that matches the feelings they have. 


\section{ACKNOWLEDGEMENT}

Thanks to the Direktorat Riset dan Pengabdian Masyarakat (DPRM ) Service that has funded this research.

\section{REFERENCES}

[1] D. P. Hallahan and J. M. Kauffman, Exceptional Children Introduction to Special Education. Virgini: Prentice hall International, Inc, 1982.

[2] J. F. Rini, “Asertivitas,” (Http:// www. E-Psikologi.com), 2001.

[3] L. Bunawan and C. S. Yuwati, Penguasaan Bahasa Anak Tunarungu. Jakarta: Yayasan Santi Rama, 2000.
[4] M. Nursalim, Strategi dan Intervensi Konseling. Jakarta: Akademia Permata, 2013.

[5] N. Abudin, Metodologi Studi Islam. Jakarta: Grafindo Persada, 2000.

[6] H. Fensterheim and J. Baer, Jangan Bilang Ya Bila Anda Akan Mengatakan Tidak. Jakarta: Gunung Jati, 1995.

[7] L. danDaisle. Willis and J., The Assertive Trainer: A Practical HandbookAssertiveness of Trainers and Running Assertiveness Course. USA: McGraw Hill, 1995. 